\title{
Influence of Finishing Operations and Melt Flow Index on Surface Quality of Injection Mol- ded Parts
}

Jiř́ Čop ${ }^{1}$, Ladislav Fojtl ${ }^{1,2}$, Ondřej Bílek ${ }^{1}$, Vladimír Pata ${ }^{1}$

${ }^{1}$ Department of Production Engineering, Faculty of Technology, Tomas Bata University in Zlín. Vavrečkova 275, 76001 Zlín. Czech Republic. E-mail: cop@ft.utb.cz, fojtl@ft.utb.cz, bilek@ft.utb.cz,pata@ft.utb.cz

${ }^{2}$ Centre of Polymer Systems, Tomas Bata University in Zlín, Trida Tomase Bati 5678, 76001 Zlín, Czech Republic

In the production of polymer parts, great emphasis is placed on the quality of polymer product in terms of dimensional accuracy and optimally surface quality. Achievement of high surface quality of injection molded products correlate to the high surface quality of core or cavity in injection molds. This surface is copied during injection of polymer material. The kind of polymer material and its rheological properties can strongly influence this surface copying. Production of cores and cavities takes in the manufacturing process a considerable part of time, where some finishing technologies are more economically and time consuming than other processes. Thus, it is necessary to choose an appropriate finishing operations considering cost of injection mold, which is reflected in future price of polymer product. This paper experimentally examines the influence of the surface quality of mold cavities and rheological properties of polymer on the surface quality of injection molded product.

Keywords: Surface quality, Injection molding, Melt flow index, Finishing operations, Polymer, Mold Cavity

\section{Acknowledgement}

This study was supported by the internal grant of TBU in Zlin No. IGA/FT/2016/002 funded from the resources of specific university research.

\section{References}

[1] BUMBÁLEK, B. (2015). Integrita povrchu a její význam pro posouzení vhodnosti dané plochy pro její funkci. [online]. [cit. 2015-11-1]. http://gps.fme.vutbr.cz/STAH_INFO/2512_Bumbalek.pdf

[2] BUMBÁLEK, L., PERNIKÁŘ, J., PATA, V. (2009). Kontrola a měrení. Informatorium. Praha.

[3] NOVAK, M. (2012). Surfaces with high precision of roughness after grinding. In: Manufacturing Technology, Vol. 12, pp. 66-70. JEPU in Ústí nad Labem, Czech Republic.

[4] GADElmaWla, E. S., KOURA, M. M., MAKSOUD, T.M.A., ELEWA, I. M., SOLIMAN, H. H. (2002). Roughness parameters. In: Journals of Materials Processing Technology. Vol. 123, pp. 133-145.

[5] GROOVER, M. P. (2012) Fundamentals of Modern Manufacturing - Materials, Processes and Systems. $5^{\text {th }}$ ed. USA

[6] GRZESIK., W. (2008). Advanced Machining Process of Metallic Materials. $1^{\text {st }}$ ed. TU of Opole, Poland.

[7] HOLEŠOVSKÝ, F., NOVÁK, M., MICHNA, Š. (2007). Studium změn broušené povrchové vrstvy při dynamickém zatěžování. In: Strojírenská technologie. pp. 73-76. JEPU in Ústí nad Labem, Czech Republic.

[8] KUNDRÁK, J. (2011). Alternative machining procedures of hardened steels. Manufacturing technology. vol. 11, no. 11., pp. 32-39, JEPU in Ústí nad Labem, Czech Republic.

[9] NOVÁK, M., HOLEŠOVSKÝ, F. (2008) Studium integrity broušeného povrchu, In: Manufacturing and Industrial Engineering. pp. 11-13. Prešov. Slovakia.

[10]MADL, J., HOLEŠOVSKY, F. (2008) Integrita obrobených povrchu z hlediska funkčních vlastností. (M. Slama., (Ed.)) 1. vyd. Ústi nad Labem : UJEP, FVTM Ústi n. Labem. Czech Republic.

[11]STANEK, M., MANAS, D., MANAS, M., SUBA. O. (2011) Optimization of Injection Molding Process. In: International Journal of Mathematics and Computers Simulation. Vol.5. Issue 5. pp.413-421.

[12]BÍLEK, O., LUKOVICS, I. (2014). Výrobní inženýrství a technologie. 1. vyd. Zlín: Univerzita Tomáše Bati ve Zlíně. Czech Republic

[13]ČILLIKOVÁ, M., MIČÚCH, M., NESLUŠAN M., MIČIETOVÁ, A. (2013). Nondestructive micromagnetic evaluation of surface damage after grinding. In: Manufacturing Technology. Vol. 13, No. 2, pp. 152-157. JEPU in Ústí nad Labem, Czech Republic.

[14]LEGUTKO, S., KROLCZYK. G., KROLCZYK, J. (2014). Quality evaluation of surface layer in highly accurate manufacturing. In: Manufacturing Technology, Vol. 14, No. 1, pp. 50-56. JEPU in Ústí nad Labem, Czech Republic. 